\title{
Renewable energy generating employment specially in Indian agriculture
}

\author{
Avinash sharma* \\ Faculty of Agriculture Sciences, Arunachal University of Studies, Namsai- 792103 \\ (Arunachal Pradesh), India

\section{Sheelawati Monlai} \\ Faculty of Agriculture Sciences, Arunachal University of Studies, Namsai- 792103 \\ (Arunachal Pradesh), India \\ Chowlani Manpoong \\ Faculty of Agriculture Sciences, Arunachal University of Studies, Namsai- 792103 \\ (Arunachal Pradesh), India

\section{Monoj Sutradhar} \\ Department of Plant Biotechnology, Bidhan Chandra Agricultural University, Mohanpur \\ (West Bengal), India

\section{Nirupa Kumari} \\ Department of Botany, Patna University, Patna (Bihar), India \\ *Corresponding author. E-mail: avinashcau@gmail.com
}

\begin{abstract}
The present review explains that renewable energy generates opportunity in field of agriculture. The renewable energy is solar energy, wind energy, water energy and biogas energy. This energy generates employment of manufacturing, design, construction, installation, operation, maintainance, supply chain, multitasking, research, development and administration. The solar industry employs 21,000 people in $2016-17$ and 25,000 people in 2017-18. The solar manufacturing industries and solar products will produce various opportunities by 2022 in India. The wind energy provides 4,40,000 employments into onshore and offshore grid system in 2008 . The wind mill industry will create $74,000 \mathrm{em}-$ ployments by 2020 in India. The water energy provides employment into hydro electric power station, manufacturing industry and others area. Biogas energy utilizes into motor vehicle as fuel. It saves petrol worth about 0.66 million per annum and also generate employment for 12 persons. The Biogas industry will set up 19 districts of the Maharashtra state to employment generation by 2020 . Renewable energy protects the earth planet. It provides employment to rural as well as urban areas. It will improve standard of living and per capita income of people. It will introduce employment to poor and literate persons. It would advocate gender uniformity and doubling of farmer income. It will improve and strengthens Gross Domestic Product and Agriculture shares in India. This energy would encourage huge transition into future era in India.
\end{abstract}

Keywords: Renewable energy, Employment, Doubling farmer income, Gender uniformity

\section{INTRODUCTION}

Renewable energy is a green energy that generates artificial energy with green technology. The light energy, water energy, wind energy, heat energy, biofuels energy and biogas energy are green energy that produces energy with renewable energy technology/green technology. The population was rise steadily in India between 1921-1951. The growth rate of population was $1.22 \%$. The population was exploded between 1951-1981. The growth rate of population was $2.2 \%$ (Population of India, facts and trends general knowledge today). The present population of

\section{Article Info}

DOI:10.31018/jans.v10i4.1940 Received: November 6, 2018

Revised: November 23, 2018

Accepted: November 29, 2018

\section{How to Cite}

Sharma, A. et al. (2018).

Renewable energy generating employment specially in Indian agriculture. Journal of Applied and Natural Science, 10(4): 1303-1307 
dominated in 2016 and it will be continued till 2030 years (Sumit et al., 2018). India has ranked 141 out of 180 countries at environmental performance index in 2016. It may cause 9 lakh premature deaths because of abrupt rise of population in 2040 (Jaijit and Sidharth, 2018). The ministry of energy and the green tribunal have focused into renewable energy. The utilization of $44 \%$ small hydro, $34 \%$ wind energy, $62 \%$ solar energy and $39 \%$ biomass has shared at electricity production in 2016-17 (CSO, 2017). The renewable energy has initiated more opportunities than non renewable energy. It would rehabilitate the ecology and abate global warming. Keeping the above in view, the present study was undertaken to review the role of renewable energy resources in generating employment in Indian agriculture.

Types of renewable energy: The renewable energy produces artificial energy with renewable energy technology. The renewable energy generates employment into several sectors i.e.Solar Energy, Wind Energy, Water Energy and Biogas Energy.

Solar energy: The Indian government had announced plan of National Solar Mission (NSM) on June 2008. The Government of India launched National Solar Mission (NSM) in 2010. The mission of this project was to drive commercial domestic industry and opportunity (Swami and Surat, 2013). The Solar energy is produced from solar energy technology. The solar energy technology is solar lanterns, solar pumps, home lighting system, street lighting, grid type solar power plant and solar industries. The solar energy technology provides direct and indirect employment. The direct employment provide opportunity in manufacturing, design, construction, installation, operation and maintainance areas and the indirect employment provide opportunity in supply chain, multi tasking, research, development and administration etc (Kammen et al., 2004). The highest solar energy technology is available in Rajasthan, Gujarat, Madhya Pradesh and Andhra Pradesh or the least solar energy technology is available into Punjab, Tamil Nadu, Karnataka, Uttar Pradesh and Telangana in India. Germany ranks first position and India ranks $12^{\text {th }}$ position into solar energy production (Business Sweden, 2015).

The rooftop solar energy generates 24.72 jobs year per mega watt and the ground mounted solar energy produces 3.45 jobs year per mega watt. The rooftop solar energy employs $2,37,980$ in out of $3,00,000$ workers and the remain workers are employ in ground mounted solar energy (Council on Energy, Environment and Water and Natural Resource Defense Council, 2016). The domestic solar manufacturing sector provides 45,000 full time employments in India (Natural Resource Defense Council, 2016). The solar industry employed 21,000 people in $2016-17$ and 25,000 people in
2017-18 (Annual Review, 2016). The Swedish company establishes solar manufacturing units, solar raw material processing and Research \& development. This company drives numerous opportunities in India (Business Sweden, 2015).

The international solar energy expo and conference was organized in Korea on June 2018. They will implement new solar market till next years. They exhibited the innovation of photovoltaic industry, solar generative products, maintainance and values or employment (Expo Solar, 2018). China employed 1.7 million jobs in solar manufacturing and solar installation. Malaysia and Republic of Korea employed in solar manufacturing. Japan employed 3, 77,000 jobs in solar photovoltaic. USA and Europe provide opportunity in solar manufacturing industry. Japan built floating solar plant that produced numerous opportunities. The solar panel road was constructed in Normandy village. This technology generated manifold opportunities in village (World Energy Council, 2016). India is emerging into solar manufacturing and solar products. It will generate various employments into large and small scale in 2022 (Annual Review, 2016).

Wind energy: Wind energy is a green energy that generates electricity. The electricity production is generated through vertical and horizontal wind mill technology. The wind mill technology was started at 2005 in India. The horizontal wind mill technology is utilized more in India. Tamil Nadu, Maharashtra, Gujarat, Karnataka, Rajasthan and Kerala uses wind mill technology to electricity production. India ranks $5^{\text {th }}$ at wind mill technology.

The progress in design and manufacturing industry was established into wind mill technology in India. The 20 plus wind turbine manufacturers are available in India. The wind mill technology drives energy security, safe climate change, achieves energy and employment. The technology generates employment into design, production, operation, maintainance, Business development. It created 7588 jobs, 6600 jobs, 4832 jobs and 4764 jobs in chikkodi district, Saundatti district, Belagavi district and Raibag district of Karnataka state (Sanjeev et al., 2016). The wind mill technology employed 2, 35,000 jobs at 2005 on onshore grid system or off shore grid system and 4, 40,000 jobs at 2008 into onshore grid system or offshore grid system (Wind energy in India, 2011). This technology generated 1,54,000 employment at Developers and manufacturers company in 2009 (Annual Review, 2011). The global wind energy of Belgian and the India wind turbine manufacturers association, New Delhi have implemented offshore grid wind mill in Karnataka. This wind mill technology will create 74,000 jobs by 2020 (India Wind Energy, 2016). The India government will set up 60 GW of wind mill technology by 2022 (Jami, 2015). This will create $3,00,000$ employ- 
ments by 2022 (International Labour Organization, 2018).

500 wind manufacturing industries are available in America. It provides amenities of installation, maintainance and transportation. The company employs 50,000 jobs in wind energy sector. The company will provide $6,00,000$ jobs in wind energy sector in 2050 (Wind Vision Report, 2015). The wind industry produces employment in manufacturing, consulting, transportation, legal, finance, meteorology, sales, marketing, logistics, communications and public relation policy etc. The US wind mill technology appointed 10, 55,000 full time employment and 23,000 full time employment into manufacturing sector in 2017. This US department of energy predicts that wind turbine will generate more than $1,00,000$ new employment and more than 5, 00,000 new employment into wind mill technology in 2030 (Wind Vision, 2016). The wind energy sector Louisiana created 4,143 direct and indirect employments. The offshore wind energy industry employed 15,00016,000 jobs in Belgian, 20,000 jobs in Denmark, 30,000 jobs in Denmark during 2017. It provided function into transformer platforms, installation of wind turbines and maintainance (Belgian offshore wind energy, 2017).

The wind energy industry produces profound opportunity. This would overcome unemployment rate in future period. This will progress into wind energy industry and will bring protection of environment.

Water energy: Water energy is a conventional energy that produces electricity. The electricity generation is supported with hydroelectric power in India. India stands seventh position into hydroelectric power in the world. The first hydroelectric power plant was established at Darjeeling in 1898 and Shivanasamudram in 1902 respectively. The hydroelectric power station has been located in the western ghats of Kerala and Karnataka. The hydropower companies of public sector are $\mathrm{Na}-$ tional hydroelectric power corporation (NHPC), Northeast electric power company (NEEPCO), Satluj jalvidut nigam (SJVN), THDC and NTPC. These companies account $92.5 \%$ hydroelectric power production into public sector in India. These companies have built hydroelectric power projects with Bhutan, Nepal, Afghanistan and another country. It provides employment in manufacturing, design, construction, installation, operation, maintainance, supply chain, multitasking, research, development and administration.

The Siang project was launched in Arunachal Pradesh for electric production. This project was established into fertile valley land. The hydropower department was allotted employment to owner of fertile valley land (Akhtar, 2014). Bhakara-Nangal Dam was constructed on Govind Sagar Lake. This dam has created huge employment into agricul- ture sector. The dam exhibits rearing and caring of fish and fish breeding. 51 species were identified from Central inland fisheries institute (Madan, 2015). The Indian government and the Bhutan government had signed agreement to Kholongchhu hydroelectric power in 2014. This agreement generates huge employment to people (Shripad, 2015).

China ranks first position in hydropower generation (Hydropower in America, 2018). The water energy creates short, medium and long term employment (Henrike, 2013). The eagle mountain energy in south eastern California appoints 500 direct and indirect employments in pumped storage. Hydroelectric equipment manufacturers were employed 550 peoples in United States (Eagle Mountain, 2014). The US hydroelectric industry employed 1 , 43,000 Americans into operation and maintainance positions in 2013 (Fact sheet, 2017). Iceland and UK signed on hydroelectric memorandum. Iceland established hydroelectric power station. The project produces long term employment in Iceland (Iceland seeks to cash on its abundant water, 2013). The US water energy department predicted that 1.4 million direct and indirect employments will create in 2025 (National Hydropower Association, 2018).

Water energy constructs low carbon environment. It will improve agriculture production and would participate into doubling of farmers' income. Hydroelectric industry, hydroelectric manufacturer will establish more employment in present and future era.

Biogas energy: The anaerobic decomposition of agriculture waste with methnaogenic bacteria to produces biogas methane. The initiation of Biogas plant was started at late 1970 in India. The Biogas energy is prepared with Biogas technology. The design of Biogas model was completed by Professor N. V. Joshi (Navindu, 2014). A social worker Mr. Jashbhai Patel initiated work on Biogas design at Khadi village industry commission in late 1940. The Janta biogas plant and the Deenbandhu digestor plant were introduced in 1978 or 1984 (Venkateswara and Saroj, 2013). The first anaerobic biogas production was completed by S.V. Desai in 1939. The ministry of agriculture had launched National Project on Biogas Development in late 1981. The Biogas technology is available in Uttar Pradesh, Tamil Nadu, Gujarat, Andhra Pradesh, Karnataka, Goa and North east region. India achieves second rank into biogas production in the world.

The Biogas technology produces employment in research, design, development, manufacture, construction, installation, operation, maintainance, updating and dismantling (Sastresa et al., 2009). The industrial development officer mentioned about current biogas project activities and promotion of biogas industries through UNIDO in the 
world. The biogas energy provides employment and income at remote areas (Alois, 2013). The Bhagirath Gramvikas Pratisthan NGO established 5000 community biogas plant at Sindhudurg and Ratnagiri districts in Maharashtra. The Surat District Cooperative Milk introduced community biogas plant at Bhintbudrak district in Gujarat. It employed jobs of supervisor, worker and labour (Indian Biogas Association, 2017). World Bioenergy Association advocated biogas technology. They suggested that Biogas energy will extend national energy security, generate employment especially in rural areas and climate change mitigation (World Bioenergy Association, 2013). India has been initiating biogas technology for the past three decades but has been unsuccessful despite several favourable environmental and sociological conditions (Indian Biogas Association, 2017). The Indian Institute Technology, New Delhi and the ministry of power, coal and renewable energy initiated National Biogas Mission on July 2015. They will set up 19 districts of the state by 2020 . This would generate employment in the biogas sectors (Biogas Forum India, 2015). The Wipro and the Mailhem Engineers Pvt. Ltd, Bangalore partnered to install, operate and maintain biogas plant. It caters 5000 employees in the plant (Business Model Profile Energy, 2008). Shyam et al., (2006) reported that biogas energy utilizes as vehicle fuel. It saves petrol worth about 0.66 million per annum and also generate employment for 12 persons. The UNDP and The Evitec Biogas India Pvt. Ltd. started project to establish Biogas plant at Namakkal district in Tamil Nadu. The mission of the project to generates employment (Evitec Biogas, 2008).

The ministry of agriculture and forestry, Finland provides subsidy to biogas production. This biogas energy is utilized into electric generation and fuel energy. It offers direct and indirect employment to people (Edita, 2006). The biogas technology provide 12 direct jobs in installation, 63 direct jobs or 43 direct jobs into operation and maintainance in Canada. The biogas energy generated 68,123 jobs in installation, $3,79,868$ jobs in operation and maintainance or 7,52, 1360 jobs in fuel supply in United Kingdom (Sarah and Hannah, 2008). The Oregon biogas industry created 300 permanent jobs in construction, manufacturing and transportation in Germany (Peter and Thadroth, 2011). The poultry farm based biogas industry policy has proposed in Bangladesh. This industry has offered less 50,000 jobs to people. Germany was the largest producer of biogas in European Union since 2015. 9000 biogas plant and 190 biomethane plant are available in Germany. It employed 810 jobs in installation, 4777 jobs in operation and maintainance, 12,537 jobs in fuel supply. The german biogas association predicts that biogas plant will generate more employment by 2000 MW per year from 2020 to 2022 (Indian Biogas Association, 2017).

Biogas energy is a clean Bioenergy that protects ecology, ecosystem and atmosphere. it provides employment in rural as well as urban sector. It will provide employment to poorest person, literate person and maintains gender equality into society. This would bring huge transformation of Indian economy.

\section{Conclusion}

Renewable energy is a clean bioenergy that will establish security to environment and will introduce direct and indirect opportunities of employment in Indian agriculture sector. There is need to implement Renewable energy centers into school at root level as well as universities that might progress the renewable energy technology with innovation, research and opportunities. Several types of manufacturing industries and enterprise could be established in society that would generate employment for skilled and unskilled persons for the production of renewable energy. This would establish gender equality revolution into society in India. This will help to generate opportunity into global commerce. Empowering and progressing in Indian Gross Domestic Product (GDP).

\section{REFERENCES}

1. Alois, P. M. (2013). Promotion of biogas in agro industries UNIDO's ongoing projects. UNIDO, 1-27.

2. Annual Review (2011). Renewable Energy and Jobs. International Renewable Energy Agency, United Arab Emirates, 1-20.

3. Annual Review, (2016). Renewable Energy and Jobs. International Renewable Energy Agency, United Arab Emirates, 1-20.

4. Belgian offshore wind energy (2017). Social \& Economic Benefits - Canadian Wind Energy Association. Ottawa, Ontario, Canada, Canwea, https:// canwea.ca/wind-facts/social-economic-benefits.

5. Business Sweden in India (2015). Opportunities in the Indian Solar Industry. The Swedish Trade and Council, 1-11.

6. Council on Energy, Environment and Water and Natural Resources Defense Council (2016). Filling the Skill Gap in India's Clean Energy Market: Solar Energy Focus. New Delhi and New York, 1-20.

7. Wind Vision Report, (2015). Advantages and Challenges of Wind Energy, Department of Energy 2050, Wind Energy Supporting 600,000 Jobs by 2050 . Energy efficiency \& Renewable energy, Washington, DC.

8. Wind Vision (2016). About the DOE Wind Energy Technologies, Energy efficiency \& renewable energy, US Department of Energy, Washington, DC.

9. Eagle Mountain pumped-storage hydropower plant (2014). Eagle Crest Energy Corporation, Desert Center, Santa Monica, CA, Desert Sun, https:// www.hydroworld.com/.../eagle-mountain-pumpedstorage-hydropower-plant-i.

10.Edita, V. (2006). Biogas and biomethane in Europe. European Biomass Association, 1-46.

11.Evitec Biogas (2008)., Detailed Project Report for 
Biogas Power Plant, Organic Fertilizer Unit in Namakkal District, Tamil Nadu, 1-132.

12.Expo Solar (2018). International Solar Energy Expo \& Conference. 1-16.

13.Fact Sheet (2017). Jobs in Renewable Energy and Energy Efficiency. Environmental and Energy Study Institute, Washington DC, EESI, http://www.eesi.org/ papers/view/fact-sheet-jobs-in-renewable-energy-and -energy-efficiency.

14.Henrike, K. (2013)., Energy and Employment: Case Study Hydropower in India. KFW Position Paper, 1-4.

15. Hydropower in America (2018). Energy Generation and Jobs Potential, Environmental and Energy Study Institute, Washington DC, Hydropower Market Report, http://www.eesi.org/briefings/view/hydropowerin-america-energy-generation-and-jobs-potential.

16. Iceland Seeks to Cash in on Its Abundant Renewable Energy (2013). Yale School of Forestry \& Environmental Studies, https://e360.yale.edu/features/ iceland seeks to cash in on its abundant renewable energy.

17.Akhtar, A. (2014). India Hydropower in Arunachal Pradesh. Heinrich Boell Foundation, Berlin, Germany, The Green Political Foundation, https:// www.boell.de/en/2014/11/14/hydropower-arunachalpradesh.

18. Indian Wind Energy (2016). A Brief Outlook, edited: Rishi, D., Lauha, F., Steve, S. and Shruti, S., Global Wind Energy Council, Brussels, Belgium, 1-20.

19.International Labour Organization (2018). Annual flagship report, World Employment and Social Outlook, Greening with jobs, Geneva, Switzerland, Promoting Jobs, Protecting People, ILO, https:// mercomindia.com/solar-wind-jobs-2022-ilo-report, 1189.

20.Jami, H. (2015). India's wind power potential. Ministry of New and Renewable Energy, Technology Report.

21.Jaijit, B. and Sidharth, T. (2018). Transformation of on-road automobiles to electric vehicles in India. KPMG International Cooperative, Swiss entity, 1-24.

22.Kammen, D. M., Kapadia, K. and Fripp, M. (2004). Putting Renewables to Work: How many jobs can the clean energy Industry Generate? In: report of the Renewable and appropriate energy laboratory. University of California, Berkley, 2-28.

23.Lakshmi, G. S., Geeta, S. R., Rajesh, S., Ambica, A., Shobha, S. and Aditya, S. H. (2017). Energy Statistics. Central Statistics Office, Ministry of Statistics and Programme Implementation, Government of India, 1-121.

24. Madan, M. M. (2015). Hydro Power Development in India Challenges \& Way Forward, Springer, 441-454.
25.National Hydropower Association (2018). Hydropower is creating jobs, (2018). New Jersey, Washington, DC, Job Creation, https://www.hydro.org/waterpower/ why-hydro/job-creation.

26.Natural Resources Defense Council (2016). Filling the Skill Gap in India's Clean Energy Market: Solar Energy Focus, New Delhi and New York, 1-20.

27. Navindu, G. (2014). Biogas Technology: towards sustainable development. Research Gate, 1-18.

28.Peter, W. and Thad, R. (2011). Growing Oregon's Biogas Industry: A Review of Oregon's Biogas Potential and Benefits. 1-16

29.Sanjeev, H. K., Tumkur, R. A. and Rajakumar, D. G., (2016). Wind Energy Development in India and a Methodology for Evaluating Performance of Wind Farm Clusters. J. Renew. Engy., 1-11.

30.Sarah and Hannah (2008)., An estimation of the job potential and assessment of skills needs for the Biogas industry in South Africa. Altgen Consulting, 1-54.

31.Sastresa, E. L., Uson, A. A., Bribian, I. Z. and Scarpellini, S. (2009). Local impact of renewable on employment: Assessment methodology and case study. Renewable and Sustainable Energy Reviews, 14 670-690.

32. Shripad, D. (2015). Hydropower in Bhutan - Time for a Rethink. Oakland CA, USA, International Rivers, https://www.internationalrivers.org/blogs/328-5.

33.Shyam, S. K., Virendra, K. V., Shivanahalli, K. R. and Rajendra, P. (2006)., Upgrading biogas for utilization as a vehicle fuel. Asian Journal on Energy and Environment, 7(04): 387-393.

34.Sumit, S., Jai, M., Sangeetha, W., Meena, S., Sachin, K., Sunil, D., Suneel, P., Anju, G., Hina, Z., Ilika, M., Atul, K. and Akshima, T. G. (2018)., Measures to Control Air Pollution in Urban Centres of India: Policy and Institutional framework. The Energy and Resources Institute, New Delhi, 1-24.

35. Swami, P. S. and Surat, P. S. (2013). Solar Energy and its Future Role in Indian Economy. International Journal of Environmental Science: Development and Monitoring, 4: (3), 81-88.

36. Venkateswara and Saroj (2013). Biogas in India. Renewable energy, Akshay Urja, 5-6: (6), 48-51.

37.Wind Energy in India (2016). Cost, opportunities, production and Government, Energy Alternatives India, Chennai, Tamil nadu, http://www.eai.in/ref/ae/ win/win.html.

38.Wind Vision Report, (2015). 20\% Wind Energy by 2030: Increasing Wind Energy's Contribution to U.S. Electricity Supply, Energy efficiency \& renewable energy, Washington, DC.

39.World Energy Resources Solar (2016). World Energy Council, Germany, 1-78. 